\title{
Damming water influences the structure, composition and functions of adjacent savannahs
}

\section{Águas represadas influenciam a estrutura, composição e funções de savanas adjacentes}

\author{
Vagner Santiago do Vale ${ }^{*}$, Ana Paula de Oliveira², Jamir Afonso do Prado-Junior ${ }^{3}$, Patrícia Ribeiro Londe ${ }^{4}$ and \\ Diego Raymundo Nascimento ${ }^{5}$
}

1 Doutor em Ecologia e Conservação de Recursos Naturais, UFU.

5 Mestrando em Ecologia, UFJF. diegoraynascimento@gmail.com

\author{
2 Doutora em Ecologia e Conservação de Recursos \\ Naturais, UFU. Instituto de Ciências Biológicas e da \\ Saúde, UFV. anadeoli@hotmail.com
}

* Corresponding author. vsvale@hotmail.com

\author{
3 Doutor em Ecologia e Conservação de Recursos Na- \\ turais, UFU. jamirjunior@yahoo.com.br \\ 4 Mestre em Geografia, UFU. Iondepr@yahoo.com.br
}

\begin{abstract}
Dams are important to human wellbeing; however, they can cause various environmental changes. In the cerrado stricto sensu, waters from the reservoir modify water supply in the soil and can affect species establishment. It is argued that species adapted to high water availability can establish close to river banks and water reservoirs and their characteristics are different from those of species from the cerrado stricto sensu. These characteristics could be more similar to those of species from riparian forests, with higher values of height and basal area. Thus, we aim to analyze changes in an area of the cerrado stricto sensu, 35 years after the construction of a hydroelectric dam. We tested different parameters to determine these changes, including richness, diversity, individual height and basal area (using the square-point method), with individuals $<1 \mathrm{~m}$, individuals $>1 \mathrm{~m}$, and Bromeliaceae (using the plot method) in three sectors close to the artificial lakeshore $(0 \mathrm{~m}-20 \mathrm{~m}, 40 \mathrm{~m}-60 \mathrm{~m}$, and $80 \mathrm{~m}-100 \mathrm{~m}$ away from the water). Using species diversity, we also compared the species functional group within these sectors. Sectors closer to the dam acted as an edge, presenting lower basal area and individual's height, but species with different traits compared to those of a cerrado stricto sensu area.
\end{abstract}

KEYWORDS: biomass accumulation, cerrado stricto sensu, tree community, hydroelectric energy, phytosociology, functional groups, functional traits.

\section{RESUMO}

Represas são importantes para o bem-estar humano, no entanto, podem causar diversas alterações nos ambientes. No cerrado stricto sensu, as águas represadas modificam o abastecimento de água no solo e podem alterar o estabelecimento das espécies. Argumenta-se que as espécies adaptadas à alta disponibilidade de água podem estabelecer-se próximo às margens de rios e reservatórios e possuem características distintas daquelas de espécies de cerrado stricto sensu. As características seriam mais semelhantes àquelas de espécies de matas ciliares, com elevada estatura e área basal. Assim, almejamos analisar as mudanças em uma área de cerrado stricto sensu após 35 anos sob a influência de uma usina hidrelétrica. Testamos parâmetros distintos para determinar essas mudanças, tais como a riqueza, a diversidade, altura dos indivíduos e área basal (utilizando o método do ponto quadrante), com indivíduos $<1 \mathrm{~m}$, indivíduos $>1 \mathrm{~m} \mathrm{e}$ Bromeliaceae (utilizando o método de parcelas) em três setores próximo à margem da represa $(\mathrm{a} 0 \mathrm{~m}-20 \mathrm{~m}, 40 \mathrm{~m}-60 \mathrm{~m}$ e $80 \mathrm{~m}-100$ $\mathrm{m}$ da represa). Utilizando a diversidade de espécies, também comparamos os grupos funcionais de espécies nesses setores. Os setores mais próximos à represa possuíam baixa área basal e altura dos indivíduos atuando como uma borda, mas com espécies com diferentes características em relação ao cerrado stricto sensu.

PALAVRAS CHAVE: acumulação de biomassa, cerrado stricto sensu, comunidade arbórea, energia hidroelétrica, fitossociologia, grupos funcionais, traços funcionais. 


\section{INTRODUCTION}

Anthropogenic impacts can lead to a structural evolution from open to closed vegetation, with increased biomass reported in various areas of the Cerrado (Moreira, 2000). Variations in water availability due to the presence of dams (Nilsson and Bergreen, 2000, Vale et al., 2013a) and fires constitute examples of anthropic disturbances that affect plant communities (Hoffman and Solbrig, 2003). In seasonal environments, such as the Cerrado, these impacts can determine the predominant physiognomy and the proportion that exists between open (savannahs) and closed (forests) areas (Marimon Júnior and Haridasan, 2005; Pinheiro and Durigan, 2009; Lopes, Vale and Schiavini, 2009); open areas have less water and experience more fires while closed areas have more water and a lower incidence of fires. In Brazil, such open savannahs are called "South American Savannahs" or "Cerrado" and are very similar structurally to the African savannahs (Dexter, 2015), with twisted trees with thick bark and a grass stratum that occupies an important portion of the vegetation, although there is variation in the floristic patterns. Here, we focus on the impact of a dam on an open cerrado plant community that became a closed forest after 35 years in proximity to the artificially water created by the reservoir.

Changes from open to closed areas are particularly important because it is not only structural aspects (such as number of trees, basal area and individual height) that are modified, but also ecological functions, such as the provision of resources for fauna and carbon assimilation (Vale, Schiavini, Oliveira and Gusson, 2010). In protected areas, such changes can alter the primary protective purpose related to the local diversity of fauna and flora, as well as influence the various biological roles played by animal and plant species.

These biological roles are related to the occurrence of species and their attributes (Walker, Kingzig and Langridge, 1999). Many species can thus play similar roles within the community and the ecosystem (Hooper and Dukes, 2004; Walker et al., 1999). These species that share the same attributes may belong to "functional groups". A functional group is a set of species with similar characteristics or that present a similar use of resources (Lyon and Sagers, 2003; Médail, Roche and Tatoni, 1998). The species within a functional group play a similar role within the community or the ecosystem (Blondel, 2003; Vale et al., 2013b). Classification into functional groups allows the gathering of a large number of species into a small group of functional types that present the same responses to disturbances or similarities in terms of processes of dispersion, competition and survival (Hubbel, 2005; Skov, 2000).

To achieve a good representation of ecological roles, we must choose traits that represent important functions relating to the ecosystems (Vale et al., 2011). However, plants have many attributes that may be used for identifying functional groups (Pendry et al., 2007) and the choice of such attributes must be clearly related to the role played by the species within the ecosystem. In this study, we focus on attributes that may represent the impacts caused by the presence of a dam. We therefore consider attributes related to local animal-plant interactions, such as pollination and dispersion, since these vary according to the availability of water and the presence of fauna and flora within an ecosystem (Nilsson, 1996).

Various animal groups can occupy different positions in the vertical space formed by vegetation. Birds, mammals (Clark, Poulsen and Parker, 2001) and invertebrates (Gossner and Muller, 2011) may prefer to occupy different vertical layers in a forest, for instance. This preference may be connected to the direct attributes of the tree community, such as the abundance of resources, temperature, leaf density, and luminosity (Campbell and Donato, 2014; O'Hanlon and Holwell, 2011; Walther, Clayton and Gregory, 1999).

Growth responses under high luminosity and mortality under shade are particularly important in forests (Pearson, Burslem, Goeriz and Dalling, 2003), but light is not restricted in open areas. Furthermore, deciduousness can interfere with luminosity at ground level, which can become more marked in soils that present a significant hydric deficit during dry periods. Furthermore, species from deciduous forests currently present rapid growth due to high carbon 
assimilation (Cornelissen, Diez and Hunt, 1996). On the other hand, evergreen species tend to produce and keep their leaves throughout the year in milder or moist environments, thus hindering the establishment of species that demand direct light below the canopy of the trees. Another important feature is tree-bark thickness; this property provides savannah species with an increased resistance to fire compared to forest species (Hoffman and Solbrig, 2003). We cannot disregard this trait, because forest areas often border the savannahs and fire events can thereby favor the savannah species (Hoffman and Solbrig, 2003).

Finally, in environments with low water availability, seed desiccation tolerance can play a key role for species survival over time. Seeds that are more tolerant to desiccation are able to survive under conditions of lower humidity without losing their viability when hydrated. Thus, the species that present this feature can constitute a persistent seed bank. In contrast, seeds that are sensitive to desiccation quickly lose their viability, although they can constitute a saplings bank in environments with high soil moisture (Tweddle, Dickie, Baskin and Baskin, 2003).

It is difficult to understand the consequences of proximity to the water line on savannah drought-adapted species, and it also remains unknown whether ecosystem functions will be lost or change after many years of dams impacts. Furthermore, dams constructions are increasing all around the world, and we must understand the changes in vegetation after damming in order to apply more appropriate conservation and management actions in the future. We assumed three hypotheses: 1) the sector close to the dam will have more forest species, with higher basal area and individual tree heights; 2) due to the presence of more closed vegetation, the sector close to the dam will have less small plants; 3) the influence of the dam will change the ecological roles within this community, with more marked effects on sectors in more close proximity to the water.

\section{OBJECTIVES}

Considering the structural and functional importance of open (in this case, cerrado stricto sensu) and closed (in this case, forest) areas, we aim to evaluate changes in a cerrado area after 35 years under the influence of a hydroelectric dam. The main objective was to understand the impacts of the dam on the savannah communities. This area was previously far from any water source, but currently lies close to a large body of water. Thus, in 2009, the entire open cerrado border became forest; however, it still preserves some cerrado characteristics, mainly at a distance from the lakeshore.

\section{MATERIAL AND METHODS}

\section{Study area and sampling methods}

This study was carried out in a forest fragment in the state of Minas Gerais, southeastern Brazil. The climate of the zone is characterized by warm temperatures throughout the year with a rainy summer and dry winter, i.e. Aw, according to Köppen (1948). The forest is located at the "Pirapitinga Ecological Station" (ESEC - Fig. 1), close to the Três Marias Dam, in Minas Gerais, Brazil. Damming took place in 1962 and ESEC became an island (GonçalvesAlvim and Fernandes, 2001). Flood elevation varies from $559 \mathrm{~m}$ to $568 \mathrm{~m}$ and the area is around 1090 ha (Azevedo, 1987). At present, the forest canopy is rarely $>10 \mathrm{~m}$ height and there are many Bromeliaceae on the ground. Species of Bromeliaceae are usually high light-demanding species that cover large areas on the ground, and clearly affect the establishment of other plant species. Far from the water, there is a transition between the forest and a cerrado vegetation. Thus we divided the forest in three sectors: 1 ) "close", i.e. 0 m - 20 m from the dam; 2) "middle”, i.e. $40 \mathrm{~m}-60 \mathrm{~m}$ from the dam, but still about $50 \mathrm{~m}$ away from the cerrado stricto sensu area; and 3) "transition", $80 \mathrm{~m}-100 \mathrm{~m}$ from the dam and closer to the typical cerrado vegetation.

We used the square-point method (Cottam and Curtis, 1956) for sampling trees. This method consists of sampling the four first trees close to the square point. Only trees with circumference at breast height $(\mathrm{CBH}) \geq 15 \mathrm{~cm}$ were included. We sampled 90 points arranged into 6 parallel transects located $100 \mathrm{~m}$ apart, for a total of 360 sampled trees. In each transect, we allocated 15 square points, 5 close to the forest border ("close"), 5 in the 


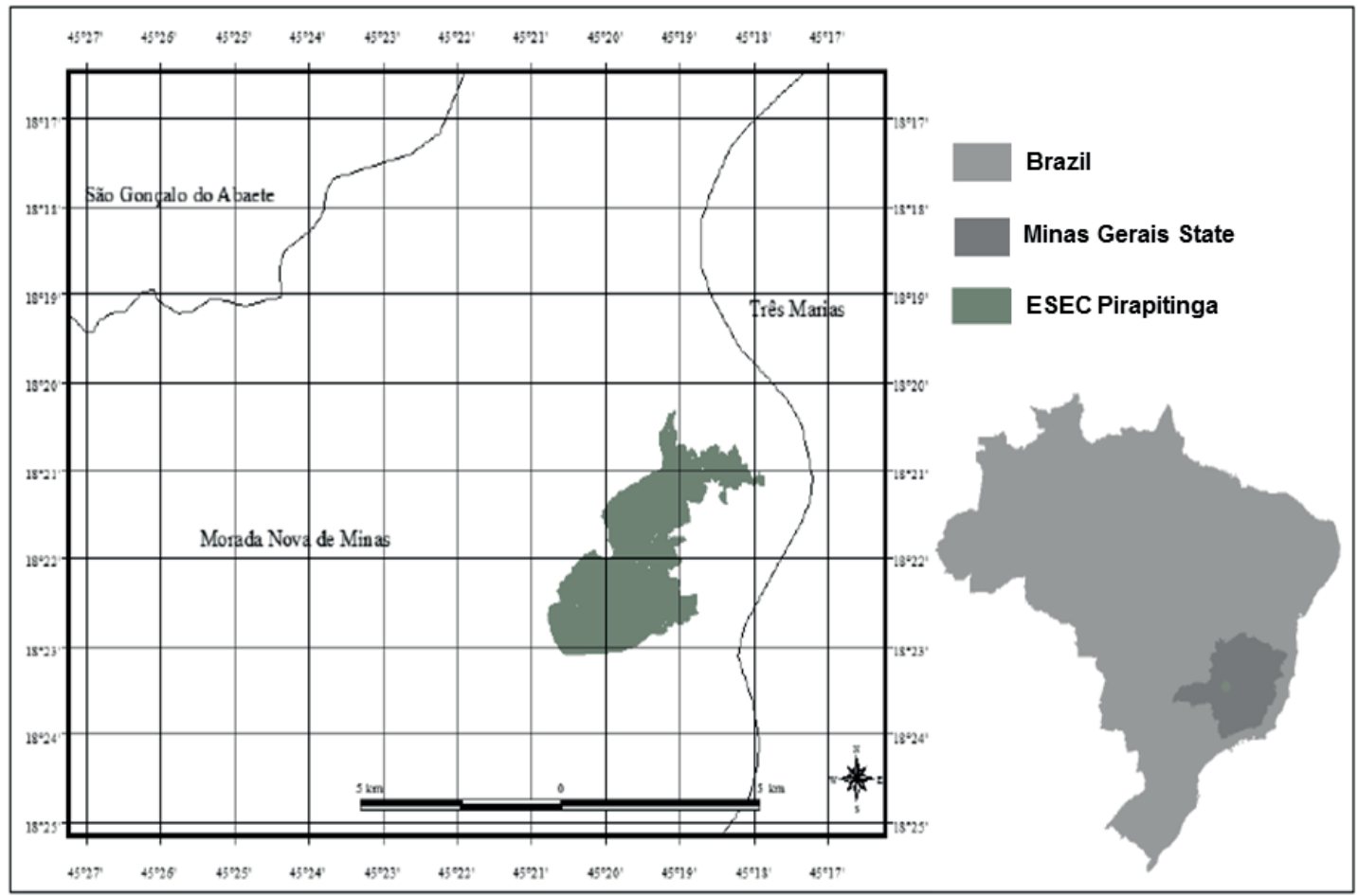

Figure 1. Location of the Pirapitinga Ecological Station (ESEC), which became an island with damming of the area 35 years ago, State of Minas Gerais, Brazil. Source: Giácomo, 2009.

middle forest ("middle"), and 5 in a transition site with cerrado stricto sensu ("transition"). Each set of 5 points in the same sector was regarded as 1 sample.

We measured all of the young trees $(\mathrm{CBH}<15 \mathrm{~cm})$, seedlings and saplings in 75 plots $(2 \mathrm{~m} \mathrm{x} 2 \mathrm{~m})$; these individuals were regarded as a regeneration layer. Regenerating individuals were classified into 2 categories: 1) seedlings, saplings, and young trees $<1 \mathrm{~m}$ height; and 2) young trees $\geq 1 \mathrm{~m}$ height. The number of species of Bromeliaceae was determined in these plots. To compare these structural parameters, we used Kruskall-Wallis and post hoc Median tests, both non-parametric tests, since the data did not comply with the assumptions of normality.

We calculated the richness and density of the arboreal and regenerating strata within the "close", "middle", and "transition" sectors. We compared the basal area and individual tree heights between these sectors using analysis of variance (ANOVA), followed by an a posteriori Tukey test with a $5 \%$ significance level (Wilkinson, 2002).

\section{Tree community functional analysis}

This analysis was performed for all tree species found within the three sectors. For each species, three physiological traits were evaluated: 1) shade tolerance, 2) deciduousness and 3) seed desiccation tolerance. In addition, two structural traits were considered: 4) vertical strata; and 5) bark thickness. Finally, there were 2 animal-plant interaction types: 6) dispersal syndrome; and 7) pollination syndrome (Table 1). We obtained information relating to the ecological attributes from scientific papers and specialized books, as well as through field observation and consulting specialists.

A matrix with the tree species and 25 traits was thus adopted for analysis. We converted data to a presence/absence matrix with species and their ecological attributes. An ecological distance matrix was then determined (Petchey and Gaston, 2002). The functional groups were revealed by two analysis types, using the distance matrix and a "cluster analysis", as explained below. 
Table 1. Traits and their respective ecological functions used for obtaining the distance matrix.

\begin{tabular}{|c|c|c|c|}
\hline Trait & Classification & Categories & Ecological function \\
\hline \multirow{7}{*}{ Dispersal syndrome' } & & & fragmentation \\
\hline & Free fall or ballistic mechanisms & Autochory & Short distance dispersion, highly affected by \\
\hline & & & fragmentation \\
\hline & Birds & Ornitochory & Medium distance dispersion, affected by frag- \\
\hline & Mammals & Mammaliochory & Short distance dispersion, highly affected \\
\hline & & & by fragmentation and food resource for the \\
\hline & & & mammals \\
\hline Deciduousness & Species in which all leaves fall & Deciduous & High litter release and canopy openness to \\
\hline
\end{tabular}

\begin{tabular}{|c|c|c|c|}
\hline \multirow{2}{*}{ Shade tolerance } & \multirow{2}{*}{$\begin{array}{c}\text { Light environment required for } \\
\text { establishment }\end{array}$} & \\
\hline & & \multirow{3}{*}{ Shade tolerant } & \multirow{3}{*}{$\begin{array}{l}\text { Low growing species and climax species; } \\
\text { related to forest maturity }\end{array}$} \\
\hline & Tolerates shade under other trees & & \\
\hline & & & \\
\hline & Needs direct sunlight to develop & Light demanding & Fast growing species; generally represents \\
\hline & & & early regeneration stages \\
\hline \multirow{5}{*}{ Vertical strata } & reached by adult individuals & & \\
\hline & Always reach the canopy & Typical canopy & Greater biomass accumulation when compa- \\
\hline & & & red to smaller species from the shade below \\
\hline & & & the canopy \\
\hline & forest layers & & is a different habitat for animals \\
\hline \multirow{6}{*}{$\begin{array}{l}\text { Seed desiccation } \\
\text { tolerance }\end{array}$} & Related to seeds remaining in situ & & \\
\hline & until next season & & \\
\hline & Seeds able to survive until next & Orthodox & Forms seed banks in the forest \\
\hline & season & & \\
\hline & Seeds unable to survive until next & Non-orthodox & Forms a "seedling bank", but not a seed bank \\
\hline & season & & \\
\hline $\begin{array}{l}\text { Pollination } \\
\text { syndrome }\end{array}$ & Species were classified by animal & & \\
\hline
\end{tabular}


TAвle 1. Traits and their respective ecological functions used for obtaining the distance matrix. Continuation...

\begin{tabular}{|c|c|c|c|}
\hline Trait & Classification & Categories & Ecological function \\
\hline & Bees with large size body (> $12 \mathrm{~mm}$ ) & Big bees & $\begin{array}{c}\text { Promotes genetic variability, and provides big } \\
\text { and isolated bees with food resource }\end{array}$ \\
\hline & Beetles & Beetles & $\begin{array}{c}\text { Promotes genetic variability. and provides } \\
\text { beetles with food resource }\end{array}$ \\
\hline & Butterflies and moths & Lepidoptera & $\begin{array}{l}\text { Promotes genetic variability, and provides } \\
\text { moths and butterflies with food resource }\end{array}$ \\
\hline & Bats & Bats & $\begin{array}{c}\text { Promotes genetic variability, and provides } \\
\text { bats with food resource }\end{array}$ \\
\hline \multirow[t]{4}{*}{ Bark thickness } & $\begin{array}{c}\text { Species were classified by stem } \\
\text { protection against fire }\end{array}$ & & \\
\hline & Stem with high bark thickness & $\begin{array}{l}\text { Highly protected } \\
\text { stem }\end{array}$ & $\begin{array}{l}\text { Prevents against fire damage. Individuals can } \\
\text { persist after a fire event }\end{array}$ \\
\hline & Rough stem & $\begin{array}{c}\text { Moderately protec- } \\
\text { ted stem }\end{array}$ & $\begin{array}{c}\text { Species can undergo fire damage and face } \\
\text { negative effects in reproductive terms }\end{array}$ \\
\hline & Stem without bark protection & $\begin{array}{l}\text { Little protected } \\
\text { stem }\end{array}$ & $\begin{array}{l}\text { Cannot prevent fire damage and the trees may } \\
\text { die following a fire event }\end{array}$ \\
\hline
\end{tabular}

$1=$ Pijl (1982); 2 = Faegri and Pijl (1979)

\section{Cluster analysis}

The groups were defined by Euclidian distance and a dendrogram generated using the group average. Multivariate clustering methods were used to determine which plant species groups could emerge. These methods calculate similarity or measurements of association, based on the extent to which species share attributes (Leishman and Westoby, 1992). Cophenetic correlation was calculated for the generated dendrogram; since this is equivalent to Pearson's coefficient, we proposed it as a concordance measure between the obtained group and the original distance matrix (Bussab and Morettin, 1990). All these analyses were performed using the software Fitopac-Shell, version 1.6.4 (Shepherd, 2004).

Once the functional groups were found, we performed analysis of variance to test differences with regard to the abundance of functional groups within the three sectors (close, middle and transition), followed by a Tukey test. The same procedure was adopted to address the abundance of species traits at all three sectors.

\section{RESULTS}

We found 57 species, 39 close to the dam, 38 in the middle sector and 29 in the transition site in the cerrado area (Table 2); however, only 18 species occurred in all three sectors. We observed 10 exclusive species in the sector close to the dam, in the middle sector there were 9 exclusive species but only 2 species were exclusive to the transition sector. Species abundance also varied between the sectors. Many species were more abundant in one sector. Alibertia edulis and Qualea parvifolia were much more abundant close to the dam. Siparuna guianensis, a typical forest understory species, was the most abundant species in the middle sector, presenting few individuals in other sectors. Vatairea macrocarpa and Qualea grandiflora, two typical cerrado species, had more individuals in the transition site in the cerrado (Table 2). 
Madera y Bosques vol. 23, núm. 1: 63-77 Primavera 2017

TABLE 2. Species list and their abundance in a cerrado physiognomy at the "Pirapitinga Ecological Station", Minas Gerais, Brazil.

\begin{tabular}{|c|c|c|c|c|c|}
\hline Species & Close to the dam & Middle & Transition & Total & Group \\
\hline Alibertia edulis (Rich.) Kuntze & 8 & 2 & 2 & 12 & G5 \\
\hline Annona crassiflora Mart. & - & 1 & 1 & 2 & $\mathrm{G} 1$ \\
\hline Aspidosperma macrocarpon Mart. & 1 & - & 3 & 4 & G2 \\
\hline Aspidosperma tomentosum Mart. & 6 & 2 & 6 & 14 & $\mathrm{G} 2$ \\
\hline Astronium fraxinifolium Schottex Spreng. & 4 & 7 & 5 & 16 & G3 \\
\hline Bowdichia virgilioides Kunth & 2 & - & 1 & 3 & G3 \\
\hline Byrsonima coccolobifolia Kunth & 1 & 2 & 3 & 6 & G1 \\
\hline Byrsonima crassa Nied. & 1 & 1 & 3 & 5 & $\mathrm{Gl}$ \\
\hline Brosimum gaudichaudi Trécul & - & 1 & - & 1 & $\mathrm{Gl}$ \\
\hline Cecropia pachystachya Trécul* & 1 & - & - & 1 & G4 \\
\hline Copaifera langsdorffii (Desf.) Kuntze & 1 & 2 & - & 3 & G3 \\
\hline Dimorphandra mollis Benth. & - & 1 & - & 1 & G5 \\
\hline Diospyros sericea A. DC. & 5 & 4 & 4 & 13 & G4 \\
\hline Dipteryx alata Vogel & - & 1 & - & 1 & G4 \\
\hline Emmotum nitens (Benth.) Miers & - & 1 & - & 1 & G4 \\
\hline Eriotheca pubescens (Mart. \& Zucc.) Schott \& Endl. & 12 & 13 & 5 & 30 & G3 \\
\hline Stenocalyx dysentericus (DC.) O. Berg & 6 & 1 & 4 & 11 & $\mathrm{Gl}$ \\
\hline Hancornia speciosa Gomes & 1 & - & - & 1 & $\mathrm{Gl}$ \\
\hline Heteropterys byrsonimifolia A. Juss. & 1 & 6 & 3 & 10 & G2 \\
\hline Hirtella gracilipes (Hook. F.) Prance & 1 & - & - & 1 & G4 \\
\hline Hymenaea stigonocarpa Mart. Ex Hayne & 1 & - & - & 1 & G1 \\
\hline Inga fagifolia (L.) Willd. ex Benth. & 1 & - & - & 1 & G5 \\
\hline Inga edulis Mart. & 2 & 1 & - & 3 & G5 \\
\hline Machaerium opacum Vogel & 1 & 1 & 1 & 3 & G3 \\
\hline Magonia pubescens A. St.-Hil & 11 & 8 & 20 & 39 & G2 \\
\hline Myrcia tomentosa (Aubl.) & 2 & - & - & 2 & G5 \\
\hline Ouratea hexasperma (A. St.-Hil.) Baill. & - & - & 1 & 1 & G1 \\
\hline Pera glabrata (Schott) Poepp. ex Baill.* & 1 & 1 & - & 2 & G4 \\
\hline Plathymenia reticulata Benth. & 1 & - & 3 & 4 & G3 \\
\hline Plenckia populnea Reissek & - & - & 1 & 1 & G1 \\
\hline Pouteria ramiflora (Mart.) Radlk. & 1 & 3 & 3 & 7 & $\mathrm{Gl}$ \\
\hline Protium heptaphyllum (Aubl.) Marchand & 2 & 3 & 1 & 6 & G4 \\
\hline Pseudobombax longifolium & - & 2 & 1 & 3 & G3 \\
\hline Psidium pohlianum (O. Berg) Landrum & 1 & - & 1 & 2 & G1 \\
\hline Pterodon pubescens Vogel & 1 & 4 & - & 5 & G3 \\
\hline
\end{tabular}


Vale et al. Damming water influences adjacent savannahs

TABLE 2. Species list and their abundance in a cerrado physiognomy at the "Pirapitinga Ecological Station”, Minas Gerais, Brazil. Continuation...

\begin{tabular}{|c|c|c|c|c|c|}
\hline Species & Close to the dam & Middle & Transition & Total & Group \\
\hline Qualea grandiflora Mart. & 2 & 5 & 10 & 17 & G2 \\
\hline Qualea multiflora Mart. & 3 & 2 & 4 & 9 & G3 \\
\hline Qualea parviflora Mart. & 6 & 1 & - & 7 & G2 \\
\hline Roupala Montana Aubl. & 1 & 2 & 1 & 4 & G2 \\
\hline Rudgea viburnoides (Cham.) Benth. & - & 1 & - & 1 & G5 \\
\hline Tachigali vulgaria Harms & - & 3 & 1 & 4 & G3 \\
\hline Siparuna guianensis Aubl. & 7 & 16 & 9 & 32 & G4 \\
\hline Siphoneugena densiflora (Krug \& Urb.) Proença* & 1 & - & - & 1 & G4 \\
\hline Styrax ferrugineus Ness \& Mart. & - & 1 & - & 1 & G1 \\
\hline Strychnos pseudoquina A.St.-Hil. & - & 2 & - & 2 & G1 \\
\hline Stryphnodendron adstringens (Mart.) Coville & 1 & 1 & - & 2 & G1 \\
\hline Tabebuia aurea (Silva Manso) Benth. \& Hook. f. ex S. Moore & 1 & - & 1 & 2 & G3 \\
\hline Handroanthus ochraceus (Cham.) Mattos & - & 1 & - & 1 & G3 \\
\hline Tapirira guianensis Aubl. ${ }^{*}$ & 1 & - & - & 1 & G4 \\
\hline Terminalia argêntea Mart. & 3 & - & - & 3 & G3 \\
\hline Vatairea macrocarpa (Benth.) Ducke & - & 1 & 9 & 10 & G3 \\
\hline Virola sebifera Aubl. & - & 1 & - & 1 & G4 \\
\hline Vochysia cinnamomea Pohl. & 1 & - & - & 1 & G2 \\
\hline Vochysia rufa Mart. & - & 1 & - & 1 & G2 \\
\hline Xylopia aromatica (Lam.) Mart. & 17 & 14 & 13 & 44 & G4 \\
\hline
\end{tabular}

* Species usually found in forest with abundant water resources.

A pattern was found in terms of basal area $(\mathrm{F}=4.32$, $\mathrm{p}=0.015)$ and individual heights $(\mathrm{F}=9.82, \mathrm{p}<0.001)$ : these structural parameters were higher in the middle sector (Fig. 2A and 2B). In the regeneration layer, the density of plants $>1 \mathrm{~m}$ height did not show a difference (Fig. 3B; $\mathrm{H}$ $=7.02, \mathrm{p}=0.30)$, however, for individuals $<1 \mathrm{~m}$ height $(\mathrm{H}$ $=26.96, \mathrm{p}=0.002)$ and bromeliad species $(\mathrm{H}=14.37, \mathrm{p}$ $=0.008)$ the lowest values occurred in the sector close to the dam (Fig. 3A and 3C).

\section{Tree functional groups}

The cluster forms 5 groups (Figure 4) and the pollination syndrome was the only species trait not useful for group formation. The 5 groups clearly have distinct functions (Table 2). Two groups present typical savannah species traits (G1 and G2): they are short (up to $6 \mathrm{~m}$ in height), deciduous species (a feature typical of seasonal environments), present prior pollination by small insects, moths and large bees (well-known pollinators in cerrado areas). Most species from both groups also have stems that are protected against fire. These groups basically differ in terms of dispersion: Group G1 provides mammals and birds with food resources while G2 is dispersed by wind. Few species from G1 are non-orthodox, meaning that this group can form both seed and seedling banks within the rainy season. 

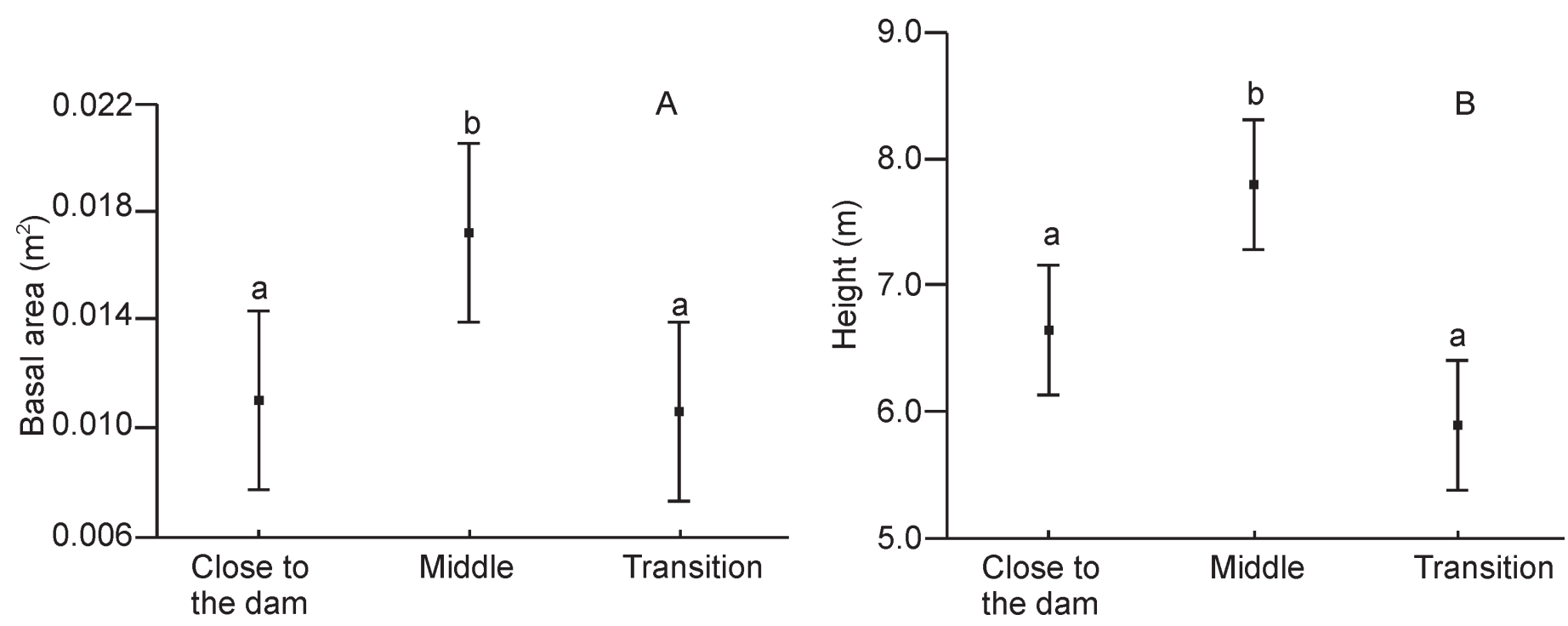

Figure 2. Analysis of variance of basal area (A) and height (B) in three sectors of a cerrado area at the "Pirapitinga Ecological Station", Minas Gerais, Brazil. Lower case letters denote the results of a post hoc Tukey test; different letters (a and b) represent significant differences $(\mathrm{p}<0,05)$.
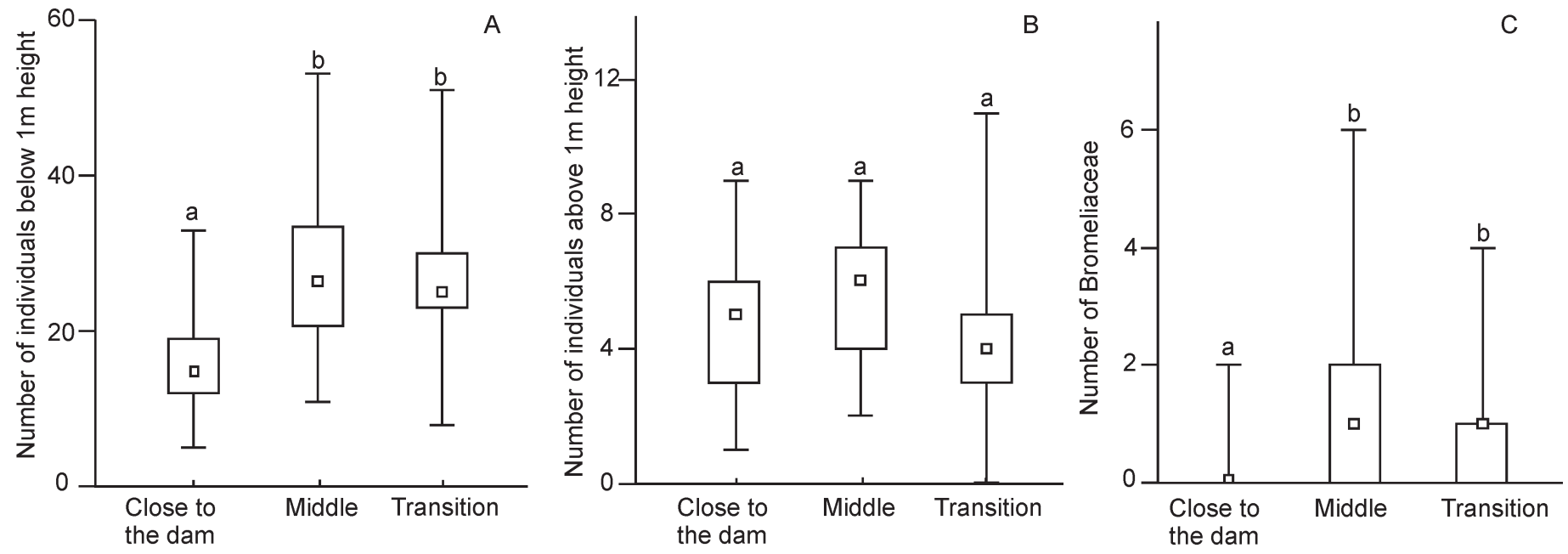

Figure 3. Kruskall-Wallis test to determine the number of individuals above and below $1 \mathrm{~m}$ in height (A and B, respectively), as well as the number of Bromeliaceae (C) in the three sectors of a cerrado area at the "Pirapitinga Ecological Station", Minas Gerais, Brazil. Lower case letters $(a, b$ and $c)$ represent the results of median test. Different letters represent significant differences $(p<0,01)$.

The other three groups are formed by traits more typical of forest species; however, they are clearly distinct. G3 and G4 are formed by taller species (usually > $10 \mathrm{~m}$ ), but G5 has strictly small trees. G3 is the only forest spe- cies group with marked deciduousness and dispersion by wind. All species have desiccation tolerance and they can form a permanent seed bank. Most species from G3 have high protection against fire, provided by thick trunks and 
barks. This group may be regarded as the most protected in case of a fire event, since, in addition to the thickness of the trunks and bark, its individuals are tall.

G4 is also a tall group; however, its individuals do not have a marked protection against fire. This may be regarded as the group most different from savannah in the forest, since it consists of many shade-tolerant species. Some species from this group, such as Protium heptaphyllum, Siparuna guianensis, Ocotea corymbosa, Pera grablata, and Tapirira guiannesis, are also observed in moist forest physiognomies. In this way, the group clearly represents the influence of the dam by considering the former cerrado vegetation. This group consists of evergreen species and provides food resources to the fauna, especially to bird species. This is the only group that presents pollination by very small insects; however, most pollination is provided by small insects, just like the other groups. This group is also non-orthodox and can form a seedling bank within the rainy season.

G5 also has non-orthodox species; however, these differ from those of $\mathrm{G} 4$, since they provide mammals and birds with food resources. This group may be highly affected by fire, because it consists of small species with no significant protection against fire. It is also the smallest group, with only 7 species - most of which are shade-tolerant species from the moist forest understory.

Comparing the groups formed close to the dam and in the middle sector, there is a lower number of short trees (G1 and G2 - groups of savannah species), a high number of tall forest trees (G3 and G4) and the highest number of short forest trees from the forest understory (G5) close to the dam (Fig. 5). The opposite occurs in the transition sector, which has a higher number of cerrado species, and the lower number of forest species, from groups 3 and 4. In the middle sector, the predominant groups were G4 and G3 (tall forest species) with few G1 and G2 trees (savannah species).

\section{DISCUSSION}

The influence of the dam on the cerrado vegetation after 35 years is clear; the tree community, previously regarded
UPGMA

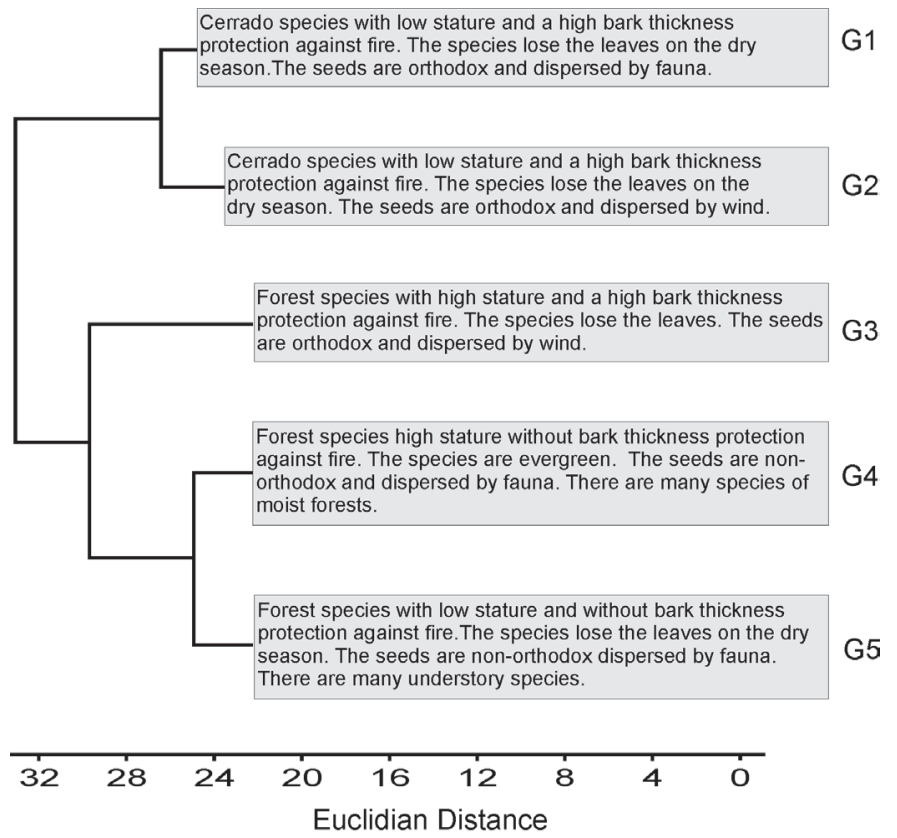

FIGURE 4. Functional groups based on ecological distance formed by clustering in a cerrado forest in southeastern Brazil. The cluster was defined by Euclidian distance and group average. Groups characteristics are shown in Table 2.

as cerrado stricto sensu (Giácomo, 2009), presented forest characteristics due to the establishment of the many forest species that currently share the space with the cerrado species. Floristic composition is still quite similar to that of cerrado vegetation, and includes species from cerrado stricto sensu, such as Qualea parviflora, Eriotheca pubescens, Magonia pubescens, and Xylopia aromatica (Ratter, Bridgewater and Ribeiro, 2003; Lopes, Vale, Oliveira and Schiavini, 2011). However, species from moist soils were also observed, such as Alibertia edulis and Protium heptaphyllum. Even small changes in the water regime can induce changes in vegetation structure (Gusson, Vale, Araújo and Schiavini, 2012; Vale et al., 2013a) and the dam clearly favors water-associated species, such as those observed in other dams (Vale et al., 2013a). Some recent studies have shown that richness can increase over time, due to the establishment of moisture-associated associated species in sectors near the lakeshore created by the 


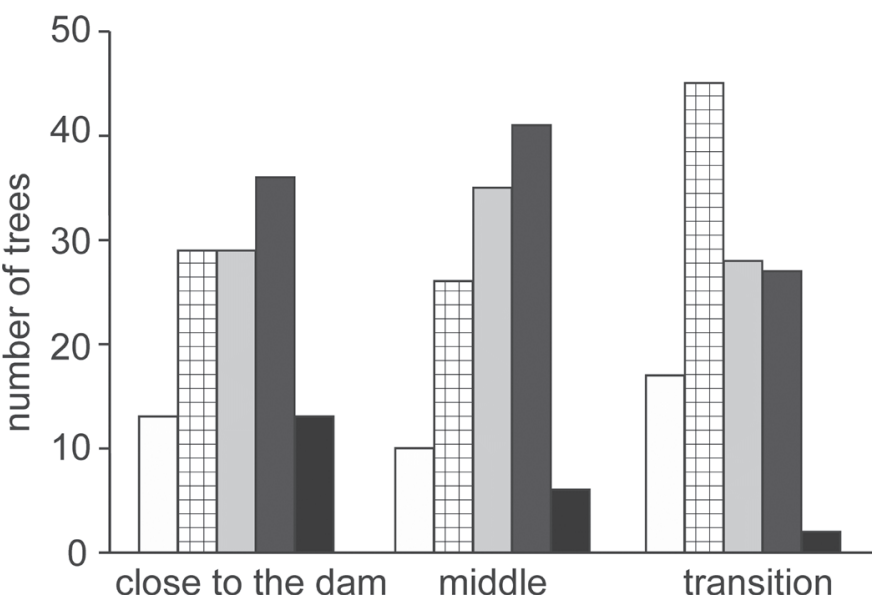

Figure 5. Number of trees found in three sectors at a forest in Três Marias Dam, Minas Gerais, Brazil.

Groups 1(white), and 2 (small squares) consist of cerrado species, G3 (light gray), G4 (dark gray), and G5 (black) consist of forest species.

dam (Vale et. al., 2015). However, for the following three reasons, this increase in species does not compensate for those lost due to the dam construction: 1) species richness in dammed riparian forests is lower than that of nondammed riparian forest (Liu, Liu, Liu, Song and Zhang, 2013); 2) the new species are different to those that existed in the area prior to construction of the dam (here the cerrado species are clearly fewer in sectors near the water and 3) the flooded area destroys the past systems, and this loss is difficult to replace.

Many of these species have thin trunks, are shadetolerant and from the forest understory. They are therefore usually short trees, such as A. edulis. Other studies show that the bark thickness of cerrado species is three times greater than that of forest species (Hoffman and Solbrig, 2003), and the basal area is even lower.

The sector close to the dam may be regarded as an edge where the wind can topple big trees, decreasing the total basal area (Laurance et al., 2006). The middle sector contained more typical canopy species, such as Astronium fraxinifolium, Pterodon pubescens, and Copaifera lansdorffi, compared to the other sectors. This sector therefore presented the highest basal area and height of trees. These canopy tree species in the middle sector are com- monly found in seasonal semideciduous forest (Lopes, Schiavini, Oliveira and Vale, 2012), which is often associated with streams, confirming that the influence of the dam can reach a distance of 40-60 m from the water's edge.

Despite the high basal area, many small trees colonize the middle sector and the large trees are distant from each other, creating open spaces. The same occurs in the transition sector, but the trees are smaller. These open patches provide sunlight conditions and facilitate the establishment of small light-demanding plants (many $<1 \mathrm{~m}$ height). The occurrence of many Bromeliaceae on the ground in the middle and transition sectors confirms the high light incidence. Savannahs are considered open areas and this feature means that these areas are still influenced by their savannah history prior to construction of the dam. Changes after damming are therefore focused on the sector close to the dam, 0 to $20 \mathrm{~m}$ far from the river, at least for some vegetation structures.

In the transition sector, the predominance of savannah species is clear; there are many individuals of species such as Qualea grandiflora and Magonia pubescens, and many other small trees, as well as large trees such as Vatairea macrocarpa. Small trees are related to forest edges (Lima-Ribeiro, 2008; Laurance et al., 2006) and both the sector close to the dam and the transition sector constitute forest edges. However, one is influenced by the dam and the other by the savannah vegetation. The middle sector is thus protected to a greater extent from border effects and consequently presents the biggest trees.

The larger number of small trees $(<1 \mathrm{~m}$ height) and Bromeliaceae (light-demanding species on the ground) in the transition sector implies an environment with more sunlight, in contrast to the sector close to the dam, which is a shaded environment. Savannah plant communities are open areas without light limitation unlike the forest, where a large amount of light is intercepted by the species that form the canopy (Poorter, Bongers and Bongers, 2006). Moreover, high soil moisture can kill seedlings and young trees due to hypoxia or anoxia (Nilsson and Bergreen, 2000), hindering plant establishment. 
Perhaps the change from a cerrado physiognomy to a forest physiognomy is not only the result of the dam. The ESEC is currently a protected area and fire, normally a common disturbance in cerrado areas, is infrequent. When protected from fire events, some cerrado communities can turn into more closed environments and, over time, can become forests (Durigan and Ratter, 2006). These areas, for instance, had not undergone a fire event for 38 years (Durigan and Ratter, 2006), facilitating the establishment of forest species, which would normally have been destroyed by fire events in the absence of any form of timber protection.

This change in functional group species (based on traits) not only suggests structural changes, but also changes in ecological roles. Forests contain a large amount of animals that forage throughout the year for fruits and pollen (Oliveira and Paula, 2001; Pinheiro and Ribeiro, 2001; Vale et al., 2013b), whereas the production of fruits and flowers in savannahs is concentrated in the late dry period (Oliveira and Paula, 2001) and resources for fauna may be insufficient during other periods.

Due to the absence of fire and/or the presence of the dam, this community clearly assumes the characteristics of a seasonal forest, since many seeds do not have desiccation tolerance, there are evergreen plants, those without bark protection and those dispersed by animals, as well as shade-tolerant trees (groups 4 and 5 are the most representative of these traits). However, some cerrado characteristics still remain, such as deciduous small trees with large bark thickness, and this may be due to their savannah history. With no fire events in the area, more forest species can establish (especially species from groups 4 and 5), assisting the conversion into forest; however, a monitoring survey would be required in order to provide further data pertaining to this issue.

\section{CONCLUSION}

After 35 years of influence of water from the dam, the cerrado stricto sensu has altered its structure, floral composition and functional traits. Patches close to the dam water now act as a forest edge and contain many water-associated species, differing strongly in this respect from a savannah. The damming influence was found at a distance of at least 40-60 $\mathrm{m}$ from the artificial lakeshore and this was evidenced by the establishment of big trees and a well developed understory, in contrast to the savannah which does not present such a structure. Functionally, the tree species that colonized these sectors (up to $60 \mathrm{~m}$ in distance from the water) had thinner bark and thus less protection against fire, were taller and did not lose their leaves in the dry season, all of which are common traits for moist forest. Clearly, many years of the dams influence has changed the community and converted an open cerrado phytophysiognomy into a closed forest community, at least within a distance of $60 \mathrm{~m}$ from the water's edge and management of these areas must take this fact into full account.

\section{ACKNOWLEDGMENTS}

We thank the two anonymous reviewers for their helpful comments, which improved the manuscript and the Programa de Concessão de Bolsa de Incentivo ao Pesquisador PROBIP (UEG) for financial support.

\section{REFERENCES}

Azevedo, L.G. (1987). Ensaio metodológico de identificação e avaliação de unidades ambientais: a Estação Ecológica de Pirapitinga, MG. Brasília, DF: Embrapa.

Blondel, J. (2003). Guilds or functional groups: does it matter?. Oikos, 100(2), 223-231.

Bussab, W. O. and Morettin, P. A. (1990). Estatística Básica. São Paulo: Atual.

Campbell, J. L., Donato, D. C. (2014). Trait-based approaches to linking vegetation and food webs in early-seral forest of the Pacific Northwest. Forest Ecology and Management, $324,173-178$.

Clark, C. J., Poulsen, J. R. and Parker, V. T. (2001). The role of arboreal seed dispersal groups on the seed rain of a lowland tropical forest. Biotrópica, 33(4), 606-620.

Cornelissen, J. H. C., Diez, P. C. and Hunt, R. (1996). Seedling growth, allocation and leaf attributes in a wide range of woody plant species and types. Journal of Ecology, 84(5), $755-765$ 
Cottam, G. and Curtis, J. T. Curtis. (1956). The use of distance measures in phytosociological sampling. Ecology, 37(3), 451-460.

Dexter, K. G. (2015). Floristics and biogeography of vegetation in seasonally dry tropical regions. International Forestry Review, 17(S2),10-31.

Durigan, G. and Ratter, J. A. (2006). Successional changes in cerrado and cerrado/forest ecotonal vegetation in western São Paulo state, Brazil, 1962-2000. Journal of Botany, 63(1), 119-130.

Faegri, K. and Pijl, L. (1979). The principles of pollination eco$\operatorname{logy}$ (3rd ed.). Oxford: Pergamon Press.

Giácomo, R. G. (2009). Fitossociologia, Aporte de Serapilheira, Estoques de Carbono e Nitrogênio em Diferentes Formações Vegetais na Estação Ecológica de Pirapitinga - MG. Unpublished master's thesis. Ciências Ambientais e Florestais. Universidade Federal Rural do Rio de Janeiro.

Gonçalves-Alvim, S. J. and Fernandes, G. W. (2001). Comunidades de insetos galhadores (Insecta) em diferentes fisionomias do cerrado em Minas Gerais, Brasil. Revista Brasileira de Zoologia, 18, 289-385.

Gossner, M. M. and Muller, M. J. (2011). The influence of species traits and q-metrics on scale-specific beta-diversity components of arthropod communities of temperate forests. Landscape Ecology, 26, 411-424.

Gusson, A. E., Vale, V. S, Araújo, G. M. and Schiavini, I. (2012). Variações temporais na densidade de espécies lenhosas regenerativas em áreas impactadas por Usinas Hidrelétricas. Revista de Biologia e Ciências da Terra, 12(1), 83-88.

Hoffmann, W. A. and Solbrig, O. T. (2003). The role of topkill in the differential response of savannah woody species to fire. Forest Ecology and Management, 180, 273-286.

Hooper, D. U. and Dukes, J. S. (2004). Overyielding among plant functional groups in a long-term experiment. Ecology Letters, 7, 95-105.

Hubbel, S.P. (2005). Neutral theory in community ecology and the hypothesis of functional equivalence. Functional Eco$\log y, 19,166-172$.

Köppen, W. (1948). Climatología: con un estudio de los climas de la Tierra. México: Fondo de Cultura Económica.
Laurance, W. F., Nascimento, H. E. M. Laurance, S. G., Andrade, A., Ribeiro, J. E. L. S., Giraldo, J. P., Lovejoy, T. E., Condit, R., Chave, J., Harms, K. E. and D'Angelo, S. (2006). Rapid decay of tree-community composition in Amazonian forest fragments. Proceedings of the National Academy of Sciences of the United States of America, 103(50), 19010-19014.

Leishman, M. R. and Westoby, M. (1992). Classifying plants into groups on the basis of associations of individual traits evidence from Australian semi-arid woodlands. Journal of Ecology, 80(3), 417-424.

Liu, W. Liu, G., Liu, H., Song, Y. and Zhang, Q. (2013). Subtropical reservoir shorelines have reduced plant species and functional richness compared with adjacent riparian wetlands. Environment Restoration Letters, 8,1-10.

Lima-Ribeiro, M.D. (2008). Edge effects on vegetation and population structure in Cerradao fragments of Southwest Goias, Brazil. Acta Botanica Brasilica, 22(2), $535-545$

Lopes, S. F., Vale, V. S. and Schiavini, I. (2009). Efeito de queimadas sobre a estrutura e composição da comunidade vegetal lenhosa do cerrado sentido restrito em Caldas Novas, GO. Revista Árvore, 33(3), 695-704.

Lopes, S. F., Schiavini, I., Oliveira, A. P. and Vale, V. S. (2012). An Ecological Comparison of Floristic Composition in Seasonal Semideciduous Forest in Southeast Brazil: Implications for Conservation. International Journal of Forestry Research, 2012. doi:10.1155/2012/537269

Lopes, S. F., Vale, V. S., Oliveira, A. P. and Schiavini, I. (2011). Análise comparativa da estrutura e composição florística de Cerrado no Brasil Central. Interciencia, 36(1), 8-15,

Lyon, S. and Sagers, C. L. (2003). Correspondence analysis of functional groups in a riparian landscape. Plant Ecology, 164(2), 171-183.

Marimon Junior, B.H. and Haridasan. M. (2005). Comparação da vegetação arbórea e características edáficas de um cerradão e um cerrado stricto sensu em áreas adjacentes sobre solo distrófico no leste de Mato Grosso, Brasil. Acta Botanica Brasilica, 19(4), 913-926.

Médail, F., Roche, P. and Tatoni, T. (1998). Functional groups in phytoecology: an application to the study of isolated 
plant communities in Mediterranean France. Acta Oecologica, 19(3), 263-274.

Moreira, A. G. (2000). Effects of fire protection on savannah structure in Central Brazil. Journal of Biogeography, 27(4), 1021-1029.

Nilsson, C. (1996). Remediating river margin vegetation along fragmented and regulated rivers in the North: What is possible?. Regulated Rivers-Research \& Management, $12,415-431$

Nilsson, C. and Berggren, K. (2000). Alterations of riparian ecosystems caused by river regulation. Bio Science, 50(9): 783-792.

O'Hanlon, J. C. and Holwell G. I. (2011). The influence of abrupt forest edges on praying mantid populations. Insect Conservation and Diversity, 4(2), 107-114.

Oliveira, P. E. A. M. and Paula, F. R. (2001). Fenologia e biologia reprodutiva de plantas de Matas de Galeria. In J. F. Ribeiro, C. A. L. Fonseca, J. C. Sousa-Silva. Cerrado: caracterização e recuperação de Matas de Galeria (pp. 303-328). Planatina: Embrapa Cerrados.

Pearson, T. R. H., Burslem, D. F. R. P., Goeriz, R. E. and Dalling, J. W. (2003). Regeneration niche partitioning in neotropical pioneers: effects of gap size, seasonaldrought and herbivory on growth and survival. Oecologia, 137(3), 456-465.

Pendry, C. A., Dick, J., Pullan, M. R., Knees, S. G., Miller, A. G., Neale, S. and Watson, M. F. (2007). In search of a functional flora-towards a greater integration of ecology and taxonomy. Plant Ecologic, 192(2), 161-167.

Petchey, O. L. and Gaston, K. J. (2002). Functional diversity (FD), species richness and community composition. Ecology Letters, 5(3), $402-411$.

Pijl, V.D. (1982). Principles of dispersal in higher plants (2nd ed.). New York: Springer Verlag.

Pinheiro, E. S. and Durigan, G. (2009). Geotecnologias aplicadas à análise da dinâmica do cerrado na Estação Ecológica de Assis, SP. In J. C. N. Epiphanio and L. S. Galvão. Anais do XIV Simpósio brasileiro de sensoriamento remoto (pp. 2905-2912). Natal, Río Grande del Norte, Brasil.

Pinheiro, F. and Ribeiro, J. F. (2001). Síndromes de dispersão de sementes em Matas de Galeria do Distrito Federal. In J. F.
Ribeiro, C.A.L. Fonseca and J.C Sousa-Silva. Cerrado: caracterização e recuperação de Matas de Galeria (pp. 335-378). Cerrados, Planaltina: Embrapa.

Poorter, L., Bongers, L. and Bongers, F. (2006). Architecture of 54 moist-forest tree species: Traits, trade-offs, and functional groups. Ecology, 87(5), 1289-1301.

Ratter, J.A., Bridgewater, S. and Ribeiro, J. F. (2003). Analysis of the floristic composition of the Brazilian cerrado vegetation III: comparison of the woody vegetation of 376 areas. Edinburgh: Journal of Botany, 60(1), 57-109.

Shepherd, G. J. (2004). FITOPAC-SHELL (Preliminar version) [Software]. Campinas: Universidade Estadual de Campinas.

Skov, F. (2000). Distribution of plant functional attributes in a managed forest in relation to neighbourhood structure. Plant Ecology, 146(2), 121-130.

Tweddle, J. C., Dickie, J. B., Baskin, C. C. and Baskin, J. M. (2003). Ecological aspects of seed desiccation sensitivity. Journal of Ecology, 91, 294-304.

Vale, V. S., Schiavini, I., Oliveira, A. P. and Gusson, A. E. (2010). When ecological functions are more important than richness: A conservation approach. Journal of Ecology and the Natural Environment, 2(12), 270-280.

Vale, V. S., Schiavini, I., Prado-Junior, J. A., Oliveira, A. P. and Gusson, A. E. (2015). Rapid changes in tree composition and biodiversity: consequences of dams on dry seasonal forests. Revista Chilena de Historia Natural, 88, 1-13.

Vale, V.S., Dorneles, M.C., Schiavini, I., Mendonça, E. T., Almeida, C. G., Silva P. A. and Crespilho, R. F. (2011). Grupos funcionais e sua importância ecológica na vegetação arbórea em um remanescente florestal urbano, Uberlândia, MG. Natureza on line, 9(2): 67-75.

Vale, V. S., Schiavini, I., Araújo, G. M., Gusson, A. E., Lopes, S. F., Oliveira, A. P., Prado-Junior, J. A., Arantes, C. S. and Dias-Neto, O. C. (2013a). Fast changes in seasonal forest communities due to soil moisture increase after damming. International Journal of Tropical Biology, 61(4), 1901-1917.

Vale, V. S., Schiavini, I., Lopes, S. F., Oliveira, A. P., Dias-Neto, O. C. and Gusson, A. E. (2013b). Functional groups in a semi deciduous seasonal forest in Southeastern Brazil. Biotemas, 26(2), 45-58. 
Madera y Bosques vol. 23, núm. 1: 63-77 Primavera 2017

Walker, B. H. (1992). Biodiversity and Ecological Redundancy. Conservation Biology, 6(1), 18-23.

Walker, B. H., Kinzig, A. and Langridge, J. (1999). Plant attribute diversity, resilience, and ecosystem function: The nature and significance of dominant and minor species. Ecosystems, 2, 95-113.

Walther, B. A., Clayton D. H. and Gregor, R. D. (1999). Showiness of neotropical birds in relation to ectoparasite abundance and foraging stratum. Oikos, 87, 157-165.
Wilkinson, L. (2002). Systat (version 10.2) [Software]. Chicago.

Manuscript received on July $23^{\text {th }} 2014$.

Accepted on December 14 2016.

This paper must be cited as:

Vale, V. S., Oliveira, A. P., Prado-Junior, J. A., Ribeiro Londe, P. and Nascimento, D. R. (2017). Damming water influences the structure, composition and functions of adjacent savannahs. Madera $y$ Bosques 23(1), 63-77. doi:10.21829/myb.2017.2311527 